Greer, C. (2007) 'News Media, Victims and Crime', in P. Davies, P. Francis, C. Greer (eds.) Victims, Crime and Society, London: Sage, pp29.

\title{
2. News Media, Victims and Crime
}

\author{
Chris Greer
}

\section{Chapter Aims \\ Introduction}

News Media and the 'Ideal Victim'

Newsworthiness, Crime and Criminal Victimisation

Newsworthiness, Crime Victims and the Importance of the Visual

Newsworthiness, Crime Victims and Institutional Failure

Under-representing Victims of Crime

Over-representing Victims of Crime

Mis-representing Victims of crime

Summary

\section{Annotated Bibliography}

References

\section{Chapter Aims}

- To problematise media representations of crime and criminal victimisation

- To discuss methods of researching criminal victimisation and media coverage

- To assess media representations of different forms of criminal victimisation 


\section{Introduction}

Chapter One offered an overview of the emergence and development of victimology, and outlined some of the conceptual, practical and political problems associated with notions of 'victim' and 'victimhood'. Not least, the definition of who may legitimately claim victim status is influenced profoundly by social divisions including, class, race, ethnicity, gender, age and sexuality, and, as such, remains a point of contention and debate. Such debates are framed and inflected, to a significant extent, in the news media. This chapter, then, is concerned critically to explore how the status of victim, and different acts and processes of criminal victimisation, are defined and represented in the news media.

It is now widely acknowledged that, across news and entertainment formats, media focus overwhelmingly on the most serious examples of crime and victimisation, foregrounding images of violent and frequently sexual interpersonal offending (Marsh, 1991; Reiner et al., 2000a). By contrast, lower level property offences that make up the significant majority of recorded crime (Maguire, 2002), and white collar and corporate offences that place a major social and financial burden on society (Hillyard et al., 2004; Tombs and Whyte, 2001, 2003; Croall, this volume), are given sparse attention, if not ignored altogether. However, the mass media focus on violent crime is also highly selective. Ferrell (2005: 150) points out that news media representations highlight 'the criminal victimisation of strangers rather than the dangerous intimacies of domestic or family conflict'. Stanko and Lee (2003: 10) note that violence in the media is constructed 'as 'random', wanton and the intentional acts of evil folk'. News reporting of crime and, 
further, of the particular types of crime on which journalists disproportionately focus, is highly selective and unrepresentative. News reporting of crime victims is equally so.

Critically exploring media representations of crime victims is important because, over the past few decades, victims have taken on an unprecedented significance in media and criminal justice discourses, in the development of crime policy, and in the popular imagination. Indeed, as Reiner and colleagues have noted, the foregrounding of crime victims in the media is one of the most significant qualitative changes in media representations of crime and control since the Second World War (Reiner et al., 2000a, b, 2003). The chapter is structured in three main parts. First, it takes a critical look at some theoretical and methodological issues which are important for researching news media representations of crime victims and criminal victimisation. Why and how these particular issues are important is illustrated by examining the portrayal of murder victims, where the influence of factors such as social divisions and inequalities and the determinants of news production is starkly illustrated. Second, it explores news representations of a range of different types of crime victim, focusing in particular on those groups and individuals who are variously over-represented, under-represented and mis-represented in media reports. Finally, the chapter identifies significant gaps in the existing research literature, raises a number of questions for further reflection, and suggests some potentially fruitful areas for future research and investigation.

\section{News Media and the 'Ideal Victim'}


Not all crime victims receive equal attention in the news media. Rather, media resources are most often allocated to the representation of those victims who can be portrayed as 'ideal'. Christie (1986: 18) describes the 'ideal victim' as 'a person or category of individuals who - when hit by crime - most readily are given the complete and legitimate status of being a victim'. This group includes those who are perceived as vulnerable, defenceless, innocent and worthy of sympathy and compassion. Elderly women and young children, it is suggested, are typical 'ideal victims', whereas young men, the homeless, those with drug problems, and others existing on the margins of society may find it much more difficult to achieve legitimate victim status, still less secure a conviction in court (Carrabine et al. 2004). In this sense, there exists a 'hierarchy of victimisation', both reflected and reinforced in media and official discourses. At one extreme, those who acquire the status of 'ideal victim' may attract massive levels of media attention, generate collective mourning on a near global scale, and drive significant change to social and criminal justice policy and practice (Greer, 2004; Valier, 2004). At the other extreme, those crime victims who never acquire legitimate victim status or, still worse, are perceived as 'undeserving victims' may receive little if any media attention, and pass virtually unnoticed in the wider social world.

In the summer of 2002, two ten-year-old girls, Holly Wells and Jessica Chapman, went missing from their home in Soham. Their disappearance attracted international media attention and precipitated the biggest ever manhunt in Britain. In 1996, two boys of similar age, Patrick Warren and David Spencer, went missing from their homes. Their disappearance failed to register much outside the local press. Shortly after 13-year-old 
Milly Dowler went missing in 2002, the body of a teenage girl was recovered from a disused cement works near Tilbury docks (Jewkes, 2004). Amidst press speculation that it was another missing teenager, Danielle Jones, who had disappeared almost a year earlier, the body was identified as that of 14-year-old Hannah Williams. Yet it was Milly's story that continued to dominate the headlines. Hannah received only a few sentences on the inside pages.

How might this media selectivity be understood? The answer lies, at least partly, in dominant conceptions of legitimate and ideal victims. Holly and Jessica were archetypal 'ideal victims'. They were young, bright, photogenic girls from stable and loving, middle-class family backgrounds, and each had an exemplary school record. David and Patrick were working class, they were boys, and they had been brought up on a rough West-Midlands council estate. They had been in trouble at school and one of them, David, had been caught shoplifting. While Holly and Jessica captured the hearts and minds of a nation, Patrick and David did not attract the same media or public interest, and few ever knew about their disappearance. Like Holly and Jessica, Milly Dowler epitomised the notion of an 'ideal victim'. By contrast, Hannah Williams was workingclass, raised by a single mother on a low income, and had run away before. Her background denied her 'deserving' victim status and, eclipsed by Milly's ongoing story, Hannah was forgotten almost immediately. Hannah Williams' murder generated just over 60 articles in the British national press, mostly after she was found. In its first two weeks alone the hunt for Holly and Jessica produced nearly 900 (Fracassini, 2002). 
The attribution or otherwise of ideal or legitimate victim status and related levels of media interest are clearly influenced by demographic characteristics. The cases of missing and murdered children discussed above indicate that both 'class' - or perhaps better, a middle-class notion of 'respectability' - and gender can be defining factors. Race, too, can be central. In 1993 black teenager Stephen Lawrence was fatally stabbed in a racist attack. At first the police assumed that because the victim was a young, black male the murder must have been gang-related (Heaven and Hudson, 2005; Cottle, 2004; McLaughlin and Murji, 1999). For a week after the stabbing in 2000 of ten-year-old Damilola Taylor in South London, news reports focused almost exclusively on the issue of community policing (Jewkes, 2004). It was not until later that both these individuals were recognised and reported as legitimate victims worthy of national media attention. Partly because of their race, and partly because of their gender, legitimate victim status was not automatic as it was for Holly, Jessica and Milly, but needed to be won. The murder of white London solicitor Tom ap Rhys Price in 2006 received 5,525 words in the national press, whilst the murder of Asian London cement merchant Balbir Matharu, killed on the same day, received only 1,385 (Guardian, $27^{\text {th }}$ January, 2006). For some, including the Chief Commissioner of the London Metropolitan Police, Sir Ian Blair, the explanation was sad but simple. The British news media are institutionally racist in how they report murder. ${ }^{1}$

There was some limited media debate regarding the merits of this allegation.

Overwhelmingly, though, the media response was hostile. Outraged newspaper editors

\footnotetext{
${ }^{1}$ The author is currently exploring, with Eugene McLaughlin, the troubled relationship between Sir Ian Blair and the media, and the reporting of murder in the British Press. A number of issues raised in this chapter emerged during discussions related to this ongoing research.
} 
reproduced high profile coverage of black and Asian murder victims - including Stephen Lawrence and Damilola Taylor - as 'proof' that they were not racist. The conservative Daily Mail, known for its 'traditionally reactionary stance on race issues in Britain' (McLaughlin ad Murji, 1999: 377), reprinted its infamous front page which risked legal action by sensationally naming and picturing the alleged killers of Stephen Lawrence beneath the headline - "Murderers: The Mail Accuses These Men of Killing. If We are Wrong, Let Them Sue us!”. (see Figure 1).

Insert Figure 1 around here - Daily Mail front page, either Feb 1997 original, or Jan $28^{\text {th }}$ 2006 centre-spread reprint

In the end, little was resolved, but the brief bout of mediatised claim and counter-claim usefully illustrated the complexity of the problem. Demographic characteristics like class, race, gender, age, and sexuality can at times determine news media interest in a fairly straightforward manner. But they can also cut across each other and interact with other variables in nuanced and unpredictable ways that do much to invalidate blanket claims that 'the press' or, still worse, 'the media' are institutionally prejudiced. The influence of victim demographics needs to be considered within the wider context of the news production process, the other elements of the case, and the prevailing cultural and political environment at that time. In order to unravel this complexity a little further, it is helpful to explore the concept of newsworthiness.

\section{Questions}




Stop now and try to think of some well known victims of crime. How would you
describe these victims? What are their demographic characteristics? Other than
their victimisation, do they share anything in common? What do your recollections
tell you about media representations of crime and criminal victimisation? What do
your recollections tell you about yourself?

\section{Newsworthiness, Crime and Criminal Victimisation}

There exists an extensive literature on the various criteria that make events attractive - or 'newsworthy' - to journalists (Chibnall, 1977; Hall et al., 1978; Katz, 1987; Ericson et al., 1989; Schlesinger and Tumber, 1994; Greer, 2003; Jewkes, 2004). Newsworthiness is shaped by 'news values' - those criteria that determine which events come within the horizons of media visibility, and to what extent, and which do not. Since the first sociological statement of news values by Galtung and Ruge in 1965, numerous commentators have offered their own interpretation of the key determinants of newsworthiness. Three important contributions are summarised in Table 1.

Table 1: Three sociological accounts of 'news values'

\begin{tabular}{|l|l|l|}
\hline \multicolumn{1}{|c|}{ Galtung and Ruge (1965) } & \multicolumn{1}{c|}{ Chibnall (1977) } & \multicolumn{1}{c|}{ Jewkes (2004a) } \\
\hline Threshold (importance) & Novelty (unexpectedness) & Threshold (importance) \\
\hline Unexpectedness (novelty) & & Violence \\
\hline $\begin{array}{l}\text { Negativity (violent, harmful, } \\
\text { deviant, sad) }\end{array}$ & $\begin{array}{l}\text { Simplification (removing shades of } \\
\text { grey) }\end{array}$ & $\begin{array}{l}\text { Simplification (removing shades of } \\
\text { grey) }\end{array}$ \\
\hline Unambiguity (clear and definite) & \multicolumn{2}{|c|}{} \\
\hline
\end{tabular}




\begin{tabular}{|c|c|c|}
\hline & Dramatisation (action) & \\
\hline $\begin{array}{l}\text { Frequency (timescale, fit within } \\
\text { news cycle) }\end{array}$ & $\begin{array}{l}\text { Immediacy (the present, fit within } \\
\text { news cycle) }\end{array}$ & \\
\hline \multirow[t]{2}{*}{$\begin{array}{l}\text { Elite-centricity (powerful or } \\
\text { famous nations or people) }\end{array}$} & $\begin{array}{l}\text { Personalisation (notable } \\
\text { individuals, celebrities) }\end{array}$ & $\begin{array}{l}\text { Celebrity or high-status (notable } \\
\text { individuals) }\end{array}$ \\
\hline & $\begin{array}{l}\text { Structured Access (experts, } \\
\text { officials, authority) }\end{array}$ & \\
\hline \multicolumn{3}{|l|}{$\begin{array}{l}\text { Composition (balance, fit with } \\
\text { other news) }\end{array}$} \\
\hline \multirow[t]{2}{*}{$\begin{array}{l}\text { Personification (individual focus or } \\
\text { causality) }\end{array}$} & $\begin{array}{l}\text { Individual pathology (individual } \\
\text { causality) }\end{array}$ & $\begin{array}{l}\text { Individualism (individual focus or } \\
\text { causality) }\end{array}$ \\
\hline & & Children (young people) \\
\hline \multicolumn{3}{|l|}{ Continuity (sustainability) } \\
\hline & Graphic presentation & \multirow[t]{2}{*}{ Spectacle or graphic imagery } \\
\hline & Visible/spectacular acts & \\
\hline $\begin{array}{l}\text { Meaningfulness (spatial and } \\
\text { cultural relevance) }\end{array}$ & & $\begin{array}{l}\text { Proximity (spatial and cultural } \\
\text { relevance) }\end{array}$ \\
\hline \multirow[t]{5}{*}{$\begin{array}{l}\text { Consonance (fit with existing } \\
\text { knowledge and expectations) }\end{array}$} & $\begin{array}{l}\text { Conventionalism (hegemonic } \\
\text { ideology) }\end{array}$ & Predictability (expectedness) \\
\hline & Titillation (exposé, scandal) & \\
\hline & & Risk (lasting danger) \\
\hline & Sexual/political connotations & Sex \\
\hline & Deterrence and repression & $\begin{array}{l}\text { Conservative ideology or political } \\
\text { diversion (deterrence, distraction } \\
\text { from wider problems) }\end{array}$ \\
\hline
\end{tabular}

Most accounts agree on certain criteria, which can be thought of as core or fundamental news values. With specific reference to crime news, most accounts also highlight the importance of violence. The observation made by Hall et al (1978: 68) three decades ago about the production of crime news still holds today:

One special point about crime as news is the special status of violence as a news value. Any crime can be lifted into news visibility if violence becomes associated with it... Violence represents a basic violation of the person; the greatest personal crime is 'murder'... Violence is also the ultimate crime against property, and against the State. It thus represents a fundamental rupture in the social order. 
Despite enduring similarities between accounts, it is important to recognise that news values are also culturally specific in that they reflect the historical and social moment in which they are situated (Naylor, 2001). As media and society change, so too can the criteria that influence the selection and production of events as news. The recent 'celibrification' of society (Rojek, 2001) would appear to have rendered anything and everything related to 'celebrity culture' newsworthy. Celebrity crime is especially so. The sexualisation of society has also affected the news (Greer and Jewkes, 2005). With the breaking down of many sexual taboos in recent decades, sex and violence are presented more frequently and graphically across all media forms (Presdee, 2000), including crime news (Reiner et al, 2000a).

At the same time, specific criminal incidents - what Martin Innes (2003, 2004) calls 'signal crimes' - can have a lasting influence on crime reporting. 'Signal crimes' are those crimes which impact not only on the immediate participants (victims, offenders, witnesses), but also on wider society, resulting in some reconfiguration of behaviours or beliefs (Innes, 2003). For example, the murder of toddler James Bulger by two ten-yearold boys in 1993 (re)generated sustained debate around the concept of 'childhood' and its intersections with 'evil and purity', 'guilt and innocence', 'care and control' (Goldson, 1997; Morrison, 1997; Scraton, 1997; James and Jenks, 1996). The racist murder Stephen Lawrence in the same year, and evidence of institutional racism in the police (mis)handling of the case (Macpherson, 1999; see also Chapter 5 in this volume), intensified interest in race and racism and their connection to 'crime and victimisation', 'law and order', 'policing and criminal justice' (Cottle, 2005; McLaughlin and Murji, 
2001). The sexually-motivated abduction and murder of eight-year-old Sarah Payne in the summer of 2000 by a convicted paedophile crystallised fears around the image of the predatory child sex offender and fuelled debate on 'risk and dangerousness', 'punishment and rehabilitation', 'surveillance and control', and the suitability of new legislation, to be called Sarah's Law, allowing limited public notification regarding the whereabouts of convicted sex offenders in the community (Silverman and Wilson, 2002; Evans, 2003). In the wake of these cases, further incidents of child violence, racist violence, predatory sexual violence were rendered more newsworthy still because they could be considered and constructed in relation to the defining incident at that time - the signal crime - which in turn could be revisited, reactivated and recreated in the media for a mass audience (Peelo, 2006). Thus, whilst violence endures as a core news value, its newsworthiness can be intensified considerably when focused through the lenses of celebrity, childhood, sex and race, among others - categories which are not in themselves new, but which have gained increased and lasting media currency due to wider social change and/or specific, high profile, signal crimes.

\section{Newsworthiness, Crime Victims and the Importance of the Visual}

What is missing from traditional accounts of crime newsworthiness is sufficient acknowledgement of the 'visual'. The rapid development of information technologies in recent decades has changed the terrain on which crime news is produced. Today, crime stories are increasingly selected and 'produced' as media events on the basis of their visual (how they can be portrayed in images) as well as their lexical-verbal (how they can 
be portrayed in words) potential. Of course, television stations are primarily concerned with producing an 'appealing visual product' (Chermak, 1995: 110). But press representations too have become intensely visual phenomena, incorporating: photographs of victims, offenders, or loved ones; diagrams mapping out a route taken, a geographical area, a weapon, or a crime scene; graphic illustrations of offending rates, prison populations, and police numbers; satirical cartoons lampooning bungling criminal justice professionals; the list goes on (see Figure 2). These visual elements of the news product depict immediately, dramatically, and often in full colour, what it may take several paragraphs to say in words. If the visual has always played an important part in the manufacture of crime news (Hall, 1973), today it has become a universally defining characteristic.

Insert Figure 2 around here - Cops Losing Fight on Violent Crime, Sun, page 33, $27^{\text {th }}$ Jan, 2006

Where victims of crime are concerned, the potential to visualise a case can have a direct impact on its perceived newsworthiness. Steve Chermak (1995: ??) begins his book Victims in the News as follows:

As the surviving family members begin to struggle with the realities of murder, they are asked by the news media to make a public obituary to the deceased victim. Journalists hope the family members can articulate their pain, suffering, and confusion in a newsworthy fashion so others can attach some meaning to the 
family's loss. The newsworthiness of this crime increases significantly if members of the family weep on camera, provide a descriptive photograph, or express their pain dramatically in words.

The press conference has become integral, both to the police investigation and to the media coverage of murder cases. Indeed, today it is almost expected that victims' loved ones will express their emotions and share their pain and suffering with media audiences, at once horrified and fascinated by the spectacle unfolding before them. As well as being assumed to increase the likelihood of public co-operation in a murder investigation, police are also aware that 'emotional displays of this kind make a good story for journalists and thus the case may receive more media attention than it might otherwise do' (Innes, 2003: 58). There is an important intersection here between the demographic characteristics of the victim and his/her relations, the availability or perceived suitability of loved ones to feature in press conferences, the overall newsworthiness of the case, and the amount of media attention it receives as a result.

The parents of Holly Wells and Jessica Chapman, Sarah Payne, and Milly Dowler all made emotional television appeals for the safe return of their children, and in some cases for information regarding the identity and whereabouts of their child's killer. Because of the ideal nature of the victims and the drama of the story, media interest in these cases was automatic. The task for the parents of Stephen Lawrence and Damilola Taylor was not so straightforward. It was not until Damilola's father travelled from Nigeria to make press and television appearances that this victim became newsworthy in his own right. 
And Doreen and Neville Lawrence campaigned tirelessly for justice, actively soliciting media attention and successfully raising the profile of the case when interest was sparse (Cathcart, 2000). Ultimately, in all of these cases articulate and 'respectable' parents were not only able, but willing, and in some cases driven to engage with the media and withstand the potentially constant glare of its spotlight. Their suitability and capability in this regard made the stories more newsworthy and, crucially, kept the cases in the public eye. Those less able or less willing to engage with the media, or those who the police consider less suitable for media exposure for whatever reason, may find that deprived of new and newsworthy material media attention quickly dries up. A police spokesperson said that Hannah Williams' background made it difficult to launch a national media campaign around her. Hannah's mother, it was claimed, a single parent on a low income, 'wasn’t really press-conference material' (Bright, 2002).

Even more powerful than press conferences, victim photographs familiarise media audiences, instantly and enduringly, with victims of crime in a way that words cannot. 'Photographs', Susan Sontag (2004: 2) argues, 'have an insuperable power to determine what people recall of events.'. Gerrard (2004: 14), writing about the Soham murders, suggests that 'We understand with words and stories, through the linked chain of events. But we recollect in pictures. Memory freeze-frames. Our lives are held in a series of vivid stills inside our head, and so it is with more public events'. And in the words of one journalist, 'If the public can see... a victim, it adds something. There is nothing to a name. When you see a picture, you see the life, the potential' (cited in Chermak, 1995: 104). In missing persons and murder cases, victim photographs are rendered more 
poignant still by the understanding that those featured may be, or already are, dead. They present an idealised personification of innocence and loss. At the same time, they serve indirectly to highlight the monstrosity and evil of the offender, and to endorse the extent to which this monstrosity 'should inform justice' (D'Cruze et al, 2006: 22). In Western culture where 'seeing is believing' (Doyle, 2003: 138) photographs humanise crime victims, adding a sense of the 'real' to that which may otherwise remain abstract and difficult to latch on to or invest in emotionally.

Thus it is not only what is known or imagined about victims, in terms of background, life history, future potential, but also how vividly that history and potential can be communicated to media audiences. In signal crimes featuring 'ideal victims', whose innocence is uncontested and whose potential is palpably felt, photographs may take on an iconic status, becoming an instant, powerful and lasting reference point. The photograph of Holly Wells and Jessica Chapman posing in their matching Manchester United shirts, or the school portraits of Damilola Taylor or Sarah Payne are good examples of victim photographs which were used relentlessly throughout each case and its aftermath, and became deeply embedded in the popular imagination. The power of these images, the newsworthiness of the crime type, the social characteristics of the victims and their families, and the suitability and willingness of those involved to engage with the media coalesced with other factors to produce a compelling narrative that connected deeply and on a profoundly personal level with media audiences, and stayed with them. Another crucial factor in sustaining their high profile presence in the news 
media was that these victims' cases featured evidence of serious failure by key institutions and agencies tasked with the role of 'public protection'.

\section{Crime Victims, Newsworthiness and Institutional Failure}

A key element in the construction of a compelling crime narrative is the attribution of responsibility or blame (Chibnall, 1977; Sparks, 1992). Blame for serious and violent crimes may be individual and directed at offenders, or less often social and directed at society. Importantly, however, it can also be institutional. When there is evidence that official agencies and state bodies assigned to protect the 'innocent' have somehow failed in this task, the potential to develop and sustain a compelling narrative is increased considerably. Media interest the deaths of James Bulger, Stephen Lawrence, Sarah Payne, Holly Wells and Jessica Chapman, and Damilola Taylor was maintained in part by evidence of serious institutional failings - variously implicating the police, the courts, the education system, even the core social institution of the family - which were portrayed either as serving to maintain the conditions that allowed the offence to occur in the first place, or impeding the case's investigation and prosecution afterwards. Now sensationally located at the heart of a scandal, the symbolic power of the victims extended beyond their individual cases and they became representative of wider issues and debates on public safety, social and criminal justice, or the nature of society itself.

When crime victims come symbolically to represent a problem that resonates with and potentially affects many in society - school safety, racist violence, knife crime - 
mediatised campaigns, particularly when launched in the victim's name, are likely to garner high levels of public support. Faced with collective moral outrage and a sustained barrage of critical media coverage, agencies publicly implicated as part of the problem, or the authorities to which those agencies are answerable, are required to respond. In each of the cases discussed above, the response was some form of official inquiry which, in turn, led to recommendations for change across structures of training and accountability, professional practice and criminal justice and social policy. The murder of James Bulger is inextricably linked to the 1998 Crime and Disorder Act's abolition of doli incapax the centuries-old legal doctrine which maintained that children between the ages of 10 and 13 could not be held fully responsible for crimes committed because they are incapable of understanding the consequences and implications of their acts. The Macpherson Report (1999) investigating the mismanagement of the Stephen Lawrence murder case branded the London Metropolitan Police 'professionally incompetent and institutionally racist' and called for fundamental change to police training and accountability, and engagement with black communities across the UK. Sarah Payne's abduction and murder by a convicted paedophile generated mediatised debate and public outrage which informed the legislative changes embodied in the Sex Offences Act 2003. The murders of Holly Wells and Jessica Chapman led directly to the Bichard Inquiry, which scrutinised the police's 'intelligence-based record keeping, vetting practices and information sharing with other agencies' (http://www.bichardinquiry.org.uk/report/) and made recommendations relevant for police, social services, education establishments, vetting services and government aimed at improving national child protection. Most recently, the conviction of two boys in 2006 for the murder of Damilola Taylor comes 
after three trials and claims that crucial forensic evidence was missed during the initial investigation. An inquiry into these institutional failures was, at the time of writing, under way. The extent to which the changes or recommendations for change following these cases have been appropriate or adequately implemented remains a matter for debate (Foster et al., 2005; Bowling and Phillips, 2002; Haydon and Scraton, 2000). For current purposes, however, what is important is the role news media played in generating, sustaining and shaping the preceding debate. It would be overstating things to suggest that media representations led directly to the policy and legislative developments that followed. But they were instrumental in publicly defining the cases, rooting the victims' images in the popular imagination, generating and focusing collective moral outrage and support for change, and, crucially, keeping the stories alive in both political and popular consciousness, in some cases long after the initial investigation had closed.

\section{Questions}

Revisit your list of crime victims. Now, consider how you are thinking about those crimes? What is it that you recall about each case? Is it the details of the offence; the media coverage - television, radio, Internet, press; the images that were released during the investigation; evidence of institutional failure?

Do you recall different things about different cases? Are you imagining the cases in words, pictures, or both? 
The first half of this chapter has discussed the significance of social divisions and inequalities, the contemporary nature of news production, and the wider criminal justice environment for the representation of crime victims in the news media. More specifically, it has sought to demonstrate the complexity of the interconnections between these factors and the impact they can have on the attribution of legitimate or ideal victim status, media interest, and the public construction of particular cases of murder. The second half of this chapter broadens out the analysis by considering news representations of a range of different types of crime victim under three broad headings: under-representing victims of crime, over-representing victims of crime, and mis-representing victims of crime. It should be noted that these headings are not mutually exclusive: victims who are underrepresented, for example, are by definition also mis-represented. The aim, however, is not to establish hermetically sealed categories of crime victim, but rather to stimulate critical thinking by demonstrating some of the ways in which crime victims and criminal victimisation can be distorted in news media representations.

\section{Under-representing Victims of Crime}

Victims of Street Crime: Though it remains the most serious examples of criminal offending that grab the biggest headlines, images of street crime and anti-social behaviour maintain a constant and foreboding presence across news media. Given the newsworthiness of violence, it is not surprising that robbery and assault feature heavily. News reports and broadcasts are replete with images of anti-social and criminally violent behaviour. Elderly women are archetypal 'ideal victims' of street crime and may attract 
considerable media attention when they become victims (see Figure 3). However, despite the impression given on some newspaper front pages, elderly women constitute one of the least 'at risk' groups (see also Walklate, this volume). As Leishman and Mason (2003: 13) point out, contrary to media stereotypes, 'victims of street muggings are typically not the vulnerable old lady having her handbag snatched, but the teenager being relieved by a coeval of a mobile phone'. What is striking about news media representations of street crime is that they relentlessly promote the image of young people as offenders, whilst downplaying their everyday experiences as victims. News media portrayals of young people as victims tend to be reserved for particularly grievous incidents resulting in serious injury or death - when they can be presented as innocent, naïve or vulnerable. This distortion led the authors of one UK media analysis to conclude, 'according to our daily press, a typical adolescent is a sporting youngster, criminally inclined [and] likely to be murdered or injured in an accident' (Porteous and Colston, 1980: 202).

Insert Figure 3 around here - Tough on Crime? They'd Laugh if it Didn't Hurt so Much, Daily Mirror, Front Page, July $12^{\text {th }} 2002$

The under-representation of young people as victims of street crime is even more pronounced for those who are non-white. High profile examples of racist murder and child killing, as we have seen, can generate enormous levels of media attention. And particular forms of criminal victimisation may be reported in racialised terms which cast black youth as victims as well as offenders. The BBC News (30 ${ }^{\text {th }}$ September, 2006), for 
example, ran a feature on gun crime which reported that $35 \%$ of UK shootings involve black victims, and that black youths are 30 times more likely to be killed through gun crime than white youths. Reinforcing Porteous and Colston's (1980) findings, however, this coverage followed a series of incidents resulting in death and portrayed the problem as an issue of 'race' as much as an issue of 'criminal victimisation'. The everyday experiences of black people as victims of crime and racial prejudice seldom make the headlines. For decades black youth have been demonised in media discourses as the 'criminal other'. Whether as pimps, rioters, muggers, Rastafarian drug dealers, gang members, or Yardies (Hall et al, 1978; Gilroy, 1987; Solomos, 1988; Alexander, 1996; Muncie, 2004), the association between race and crime has been forcefully established and remains resonant today. This association has more recently extended to Asian youth (Alexander, 2000). Once perceived as more likely to fall victim to street violence than perpetrate it (Muncie, 2004), participation in events like the anti-Rushdie protests of 1989 and demonstrations against the first and second Gulf Wars have resulted in an intensified media interest in potential Asian criminality. An Independent article in 1995, warning of 'an Asian crime "timebomb", cautioned that 'the country is on the verge of an outbreak of disorder caused by Asians... which could shatter the belief that Asians are more lawabiding than white or black people'. In a post-September $11^{\text {th }}$ world of heightened 'Islamophobia', fear and suspicion of Asian youth is exacerbated by news reports which crudely, but commonly, marry the terms 'Asian' and 'Muslim', on the one hand, and 'Islam' and 'Islamic fundamentalism', on the other. Racialised discourses on asylum and immigration inflame tensions still further (ICAR, 2007; Greer and Jewkes, 2005). Meanwhile, Asian youth 'resistance' against perceived or actual victimisation by the state 
and wider society becomes 'synonymous with criminality and upheaval, with the breakdown of perceived traditional values and the growth of a pathologised culture of alienation and confusion' (Alexander, 2000: 7). The apparent news media obsession with the criminality of non-white youth displaces interest in their experiences of all but the most serious forms of criminal victimisation.

Victims of White Collar and Corporate Crime: The most notable thing about white collar and corporate offending in the media is their general lack of prevalence and prominence relative to 'traditional' or 'conventional' crimes of interpersonal and sexual violence. This apparent lack of media interest can be related back to the previous discussion of newsworthiness and the allocation of blame. Unlike many street crimes, corporate and white collar offences are often 'morally ambiguous in terms of crime, criminal and victim; they unfold slowly; and they do not culminate in a clear resolution' (Cavender and Mulcahy, 1998: 699). While traditional crimes at some point necessarily involve a degree of proximity between victim and offender, victims of corporate and white collar crime may never actually encounter the offender and, still further, may never realise they have been victimised - for example, in cases of large scale, financial fraud or embezzlement, where individual losses are small but the cumulative total may run into millions (Croall, 2001a, Stephenson-Burton, 1995). When individuals are aware of their victimisation, it may be impossible to evidence the precise source of harm, still less prove individual or corporate legal culpability - for example, victims of long term environmental pollution or corporate negligence resulting in deaths at work (Tombs and Whyte, 2001). Even when both crime and victim are clearly identifiable, the media's 
preferred image of the 'ideal victim' can be difficult to establish. In the case of health and safety violations, as Tombs and Whyte (2007) point out, the media portrayal of employees as innocent victims may be directly challenged by corporate discourses which seek to abrogate liability by presenting individuals as 'accident-prone' and thus partly to blame for their own injury. Investors who are defrauded may be perceived as partly responsible for making 'risky' or 'ill-informed' financial choices and, as a result, receive little attention outside the specialist business and financial press. Older people who are 'taken advantage of', or ordinary folk who are victimised by corporate 'fat cats', may be seen as more deserving of 'legitimate' victim status (Levi, 1999), and receive more mainstream media attention.

Due to the difficult to prove and frequently diffuse nature of the harm caused by white collar and corporate victimisation, these offences feature much less in our immediate experience. They do not arouse the same levels of fear and moral indignation as offences of interpersonal violence. The language of news coverage contributes further to muting moral outcry and inhibiting emotional identification with victims of these offences. Reports describe health and safety 'accidents' rather than 'criminal negligence'. Financial assets are 'plundered' or 'lost', rather than 'stolen'. Individuals are 'defrauded' rather than 'robbed'. Furthermore, as Stephenson-Burton (1995: 147) notes, there is often a 'grudging respect, or at the very least a lessening of antipathy, within media representations of the white collar criminal'. So despite the fact that the economic, social and physical harm done can be enormous (Croall, 2001b; Tombs, 2005), white collar and 
corporate offending continue to suffer from relative media invisibility, with the victims remaining less visible still.

\section{Over-representing Victims of Crime}

Police and Prison Officers as Crime Victims: Discussions of ideal and legitimate victims have so far focused on members of the public. Another important manifestation of the 'ideal victim', at times no less potent in terms of generating sustained media attention and public outcry, is the police or prison officer killed in the line of duty. Whilst many victims of crime are under-represented in the news media, it can be cogently argued that the criminal victimisation of police and prison officers is, if anything, over-represented. Greer (2005: 165) has noted the news media priority given to police officers killed on duty: 'On $26^{\text {th }}$ December 2003 Iran was struck by an earthquake which killed upwards of 25 thousand Iranian citizens. This was a natural disaster on a massive scale, and the second story reported on the UK evening News at Ten. The headlining item disclosed that an English police officer had been shot'.

The suggestion is not that those state servants killed in the line of duty are undeserving of media attention or, in some cases, national recognition and public mourning. Rather, the point is that news media representations tend to exaggerate both the prevalence and the seriousness of incidents involving prison and police officers, whilst the victimisation of the marginalised and the powerless is frequently overlooked. Sim (2004) argues that this mediatised impression of vulnerability and danger is, in fact, at odds with the available 
statistical information. Most of the deaths of on duty police and prison officers occur through natural causes, such as heart attacks, or accidents, such as car crashes. Very few deaths result from murder by inmates or offenders. Nevertheless, the murders of police and prison officers are highly newsworthy to journalists because they can be portrayed as ruptures to the social fabric of society, reinforcing the perennially popular media themes of decline, disorder and lack of respect for authority (Chibnall, 1977). At the same time, these statistically rare, isolated incidents allow representative bodies, like the Prison Officer Association and the Police Federation, to symbolically construct all their members as both 'heroes' and 'victims', carrying out dangerous work under constant threat of murderous violence from inmates and offenders. Prisons are portrayed as harmful and dangerous places for prison staff alone, whilst the dangers faced by prison inmates at the hands of staff and each other receive scant media attention. The number of police officers killed the line of duty is eclipsed by the number of people who die in police custody each year, yet whilst the former may dislodge the deaths of 25,000 Iranian citizens as lead news item, the latter seldom causes much of a news tremor. As Sim notes (2004: 116), the cumulative effect of over-representing 'the victimised state', whilst at the same time under-representing the victimisation of some of society's most powerless and marginalised groups, sometimes at the hands of the state, contributes to building a 'consensus around the essential benevolence of state institutions and their servants particularly police and prison officers - while simultaneously socially constructing these same servants as living in perpetual danger from the degenerate and the desperate'. For critical criminologists, this ideologically loaded selectivity contributes to buttressing the legitimacy of the prevailing criminal justice system, maintaining the perceived sanctity of 
state servants as guardians of order, and supporting the development of authoritarian, law and order politics.

\section{Mis-representing Victims of Sex Crime}

Victims of the Criminal Justice System: When they are victims of serious criminal victimisation, police and prison officers tend to attract high levels of ideologically loaded media coverage. When those who have been caught up in the criminal justice net, therefore already branded offenders, fall victim to the pressures of the criminal justice system, media coverage is often less copious, but no less ideologically loaded. Drakeford (2006) illustrates how the 2004 prison suicide of 14 year old Adam Rickwood - the youngest child ever to take his own life while in the care and custody of the British penal system - was characterised in the conservative Daily Mail as bad from the start. His death was described as the closing scene in 'a bleak tale of family breakdown, and an absence of discipline, as well as a blasé acceptance of drug-taking, underage drinking and petty theft' (Daily Mail, 16 ${ }^{\text {th }}$ August, 2004, in Drakeford 2006). As Drakeford (2006: 218) notes, a 'cultural hegemony, reinforced by media reporting, links 'youth' and 'crime' in the public mind in a way which dissolves these categories into one, regarding those caught up in the criminal justice system as simply reaping the rewards of their own culpability'. The Zahid Mubarek in Feltham Young Offenders Centre in 2000, bludgeoned to death with a table leg by his racist cellmate, led to an official inquiry. The release of the Inquiry Report (Keith, 2006) received considerable media attention, not least because it listed more than 180 'failings' in the penal system, branding the sequence 
of events 'institutional racism leading to institutional murder'. News stories in this case were less about the deprived or depraved background of the victim, and more about the gaping holes in criminal justice policy and practice which would allow a vulnerable inmate to be incarcerated in the same cell as a persistently violent offender with a history of racist assault and suspected severe personality disorder. Even here, then, whilst there was no 'spoiling' of the victim's identity, as there was with Adam Rickwood, it was the newsworthiness of exposing institutional failure and attributing blame to those in authority that dominated coverage.

Adult Victims of Sex Crime: Several commentators have pointed to the highly gendered reporting of male sexual violence against women (Soothill and Walby, 1991; Benedict, 1992; Lees, 1995; Greer, 2003). Soothill and Walby (1991: 22) argue that during the tabloid wars of the late 1970s sex crime was presented by some newspapers as a form of 'soft pornography' to increase sales. Twenty years on Lees (1995: 125) evidenced little change and found much rape reporting in a sample of four British newspapers to be 'biased, inaccurate and irresponsible', and frequently 'directed at discounting women's allegations of rape, and justifying the masquerading of rape as seduction'. Benedict (1992) has highlighted the tendency for news media to polarise women in sex crime cases into either 'virgins' or 'whores', or, in the language of this chapter, 'ideal' and 'undeserving' victims. These binary oppositions do not necessarily result from individual journalistic malice. Rather, they arise from the gender-biased nature of language and prevailing myths about women, sex and rape. These myths implicitly guide news making in a way that can influence even the most well meaning commentators, so 'a myth- 
saturated woman will be just as insensitive to rape cases as a myth-saturated man, especially given the conditions and habits of newsroom behaviour' (ibid. 1992: 6). Meyers (1997: 119) has found a similarly biased coverage of female victims of sexual violence, noting that news coverage is influenced heavily by the 'virgin-whore' dichotomy, and by notions of race, class and age which result from the convergence of 'male and white supremacist ideologies'. The finding across these studies and others are remarkably consistent. News media representations of adult victims of sex crime, if seldom presented as soft pornography today, are frequently structured and couched in highly masculinist terms which do much to maintain traditional patriarchal stereotypes of femininity, masculinity and 'appropriate' female sexuality, whilst doing little to challenge prevailing myths about rape and tackle the problem of male sexual violence against women.

Child Victims of Sex Crime: Perhaps the most significant shift in media reporting of sex crime in recent decades has been the emergence of child victims as a news staple, and the decline in attention to adult rapes unless there is some additional, novel aspect to the case - for example, the involvement of celebrities, or multiple victims or offenders (Greer, 2003). Even though child sex abuse reporting has proliferated, it is only certain types of offence that receive regular and sustained coverage. News stories tend to feature very young victims - well below the age of consent and thus easily presented as completely 'innocent' - who have been abused by a stranger, someone in a position of authority say a teacher, youth leader or member of the clergy - or, more recently, groomed online. Sexual victimisation often takes place within the home, and it is more likely a child will 
be abused by someone to whom they are related than by a stranger or someone just met (Grubin, 1998). Yet images of familial abuse are virtually absent from mainstream media representations. Kitzinger (1999) points out that whilst people may on some level be aware that the greatest dangers to children frequently come from within the home, their fears focus on external threats - scrubland rather than living rooms, strangers rather than family members - because this is both practically and emotionally more manageable on a day-to-day basis. Whilst such fears may be understandable and are no doubt shared by many of the journalists who produce the news, they nonetheless contribute to sustaining a highly selective and misleading representation of child sexual abuse in the media. In particular, the emphasis on the most serious examples of child sexual victimisation by strangers both reflects and reinforces fears of the unknown predatory 'other', and at the same time inhibits full and informed discussion about the nature and extent of sexual violence in society and the measures that might best be taken to protect those most at risk.

\section{Questions}

Why is it that some forms of crime victim and criminal victimisation feature so prominently in the media, whilst others are scarcely mentioned or discussed? What additional forms of criminal victimisation, not discussed in this chapter, are reported in the media? What characterises those media representations?

\section{Summary and Conclusions}


This chapter has identified and explored some of the key influences that shape the representation of crime victims and criminal victimisation in the news media. It has explored the relationship between social divisions, inequality and 'ideal' or 'legitimate' victim status, examined how changes in the media environment and the news production process have impacted on the representation of crime victims, and considered reporting of a range of different victim types who are variously over-represented, underrepresented or mis-represented in news media discourses. These closing paragraphs offer a few points by way of summary, raise some questions which seem pertinent at the present time, and suggest a number of potentially fruitful areas for further research and investigation.

Over the past thirty years or so, shifts in 'official' and 'academic' thinking, accompanied by wider political and cultural change, have contributed to generating a climate in which 'system discourses' are often pitched in vain against 'victim discourses' (Garland, 2000). At a time of widespread intolerance, anxiety and fear of the unknown 'other', those who are seen to represent the interests of offenders occupy an uncomfortable and, at times, deeply unpopular place within public hearts and minds (Greer, 2003). In stark contrast, those who speak for victims are seen to speak for us all. Yet the victim voices that find resonance in the media represent only a small fraction of those who experience criminal victimisation. What this chapter demonstrates, along with the other contributions in this volume, is that those who feel the pains of victimisation most acutely are often those whose voices are stifled rather than amplified in news media discourses. 
It is not simply the case that race, gender or any other social division retains an overarching and static defining influence over media interest in crime victims and their subsequent representation in the news. Reporting criminal victimisation is more fluid and dynamic than this, and can change from case to case and over time. Implicitly promoting the view that news media, like any other institution, are capable of reflexive learning, many journalists would contend that since Stephen Lawrence the news media have learned how to 'do race', if perhaps not yet 'class'. That there is evidence both for and against this claim - some of which has been discussed in this chapter - serves to further highlight the variability of news representations and the dangers of settling for blanket generalisations about the prejudices of the 'the press' or 'the media'. Nevertheless, it remains the case that much news coverage of criminal victimisation both reflects and reinforces social divisions and inequalities, and in so doing feeds into the wider structures of power, dominance and subjugation from which they derive. It is perhaps less in the sensational reporting of high profile murder cases, and more in the representation of victims of everyday crime, prejudice and abuse that these inequalities, though less dramatically conveyed, continue to have the greatest impact. This impact can be seen in the selective portrayal of those victims who come within the horizons of newsworthiness. Equally, however, it can be evidenced through consideration of those who do not.

Unfortunately, the selective representation of crime victims in the news media has been reflected in much criminological research. With the important exception of feminist studies on sexual and domestic violence, and the work of some critical criminologists 
discussed above, what little research there is exploring crime victims in the media has tended to focus mostly on those types of crime and victim that maintain a strong media presence. It is also crucial also to consider those victims and processes of criminal victimisation which remain absent from the news. More attention, for example, could be directed at researching the media representation (or lack of representation) of victims of the powerful: corporate crimes, deaths in custody, war crimes and genocide. A number of key, and as yet largely unanswered, questions stem from these observations:

- How do different groups, interests and individuals go about soliciting and sustaining media interest in particular crime victims, or types of victim?

- What precisely are the conditions that need to be in place before victimised members of marginalised and powerless groups are deemed worthy of media attention and public sympathy?

- What are the hierarchies of credibility and power in a multi-mediated society where images increasingly interweave with the worldwide practice of crime, violence, war and justice?

- What precisely is the everyday impact of the selective representation of crime victims and criminal victimisation on popular crime consciousness?

The answers to these questions are complex and difficult to research, and anything short of an 'ethnographic approach' is unlikely to make much headway (Chermak, 1995; Greer, Ferrell and Jewkes, 2007). But this does nothing to diminish their importance. In the information age (Webster, 2005), news images and media debates are a central 
influence in shaping popular notions of who can rightly claim legitimate victim status, informing victim policy formation and, ultimately, helping to shape the structures of training, accountability and professional practice directing at protecting the public and responding to victims of crime. Deconstructing the power dynamics, information flows, social relations and political struggles between all those involved in the news production process is a pressing sociological project. Just like so many crime victims who remain marginalised or ignored in official discourses, understanding the role of media in constructing and representing crime victims and criminal victimisation cannot remain on the periphery of academic enquiry. Rather, it should be a central concern for all those wishing seriously to engage with the political economy of crime, control and social order in contemporary society.

\section{Annotated Bibliography}

Chermak, S. (1995) Victims in the News: Crime and the American News Media, Boulder, CO: Westview Press.

One of the only book-length studies to be conducted specifically on media representations of crime victims, this study is an in-depth qualitative analysis of the American news media with a strong ethnographic edge.

Cottle, S. (2004) The Racist Murder of Stephen Lawrence: Media Performance and Public Transformation, Westport: CT Praeger. 
A sophisticated book-length analysis of the Stephen Lawrence case and its construction and 'performance' in the media, exploring the rhetoric of journalism, the dynamics and contingencies within both politics and storytelling, and the strategic interventions of various groups, interests and identities.

\section{Crime, Media Culture: An International Journal, London, Sage (edited by Yvonne}

\section{Jewkes, Chris Greer and Jeff Ferrell)}

This journal offers a forum for exchange between scholars who are working at the intersections of criminological and cultural inquiry. It promotes a broad crossdisciplinary understanding of the relationship between crime, criminal justice, media and culture, and regularly features article on media methodology, news production, and crime victims and criminal victimisation.

Greer, C. (2003a) Sex Crime and the Media: Sex Offending and the Press in a Divided Society, Cullumpton: Willan.

This book presents an in depth quantitative and qualitative analysis of the press reporting of sex crime, including interviews with all the key players in the news production process and, like Chermak's study, a strong ethnographic edge.

\section{Schlesinger, P. and Tumber, H. (1994) Reporting Crime: The Media Politics of Criminal Justice, Oxford: Clarendon Press.}

Still one of the best qualitative studies of crime reporting in the news and on television, this book includes general discussions of newsworthiness, crime reporting and the wider 
crime and justice environment, and in-depth case studies exploring how particular acts of criminal victimisation were portrayed in the British news media. 


\section{References}

Alexander, C. (1996) The Art of Being Black, Oxford: Oxford University Press.

Alexander, C. (2000) The Asian Gang: Ethnicity, Identity, Masculinity, Oxford: Berg.

Benedict, H. (1992) Virgin or Vamp, Oxford: Oxford University Press.

Bichard, Sir M. (2004) The Bichard Inquiry: Report, HC653. London: The Stationary Office.

Bowling B and Phillips C (2002) Race, Crime and Justice London: Home Office.

Bright, M. (2002) 'The Vanishing', in Observer Magazine, $15^{\text {th }}$ December.

Carrabine, E., Iganski, P., Lee, M., Plummer, K. and South, N. (2004) Criminology: A Sociological Introduction, London: Routledge.

Cathcart, B. (2000) The Case of Stephen Lawrence, London: Penguin.

Cavender, G. and Mulcahy, A. (1998) 'Trial by Fire: Media Constructions of Corporate Deviance', in Justice Quarterly, 15, 4: 697-719.

Chesney-Lind, M. and Eliason, M. (2006) 'From Invisible to Incorrigible: The Demonisation of Marginalised Women and Girls', in Crime, Media, Culture: An International Journal, 2, 1: 29-47.

Chermak, S. (1995) Victims in the News: Crime and the American News Media, Boulder, CO: Westview Press.

Chibnall, S. (1977) Law and Order News: An Analysis of Crime Reporting in the British Press, London: Tavistock.

Christie, N. (1986) 'The Ideal Victim' in E. Fattah (ed.) From Crime Policy to Victim Policy, Basingstoke: Macmillan.

Corner, J. (2004) 'Afterword: Framing the New,' in S. Holmes and D. Jermyn (eds) Understanding Reality Television. London: Routledge. 
Cottle, S. (2005) 'Mediatized Public Crisis and Civil Society Renewal: The Racist Murder of Stephen Lawrence', in Crime, Media, Culture: An International Journal, 1, 1: 49-71.

Cottle, S. (2004) The Racist Murder of Stephen Lawrence: Media Performance and Public Transformation, Westport: CT Praeger.

Croall, H (2001a) Understanding White Collar Crime Buckingham: Open University Press

Croall, H (2001b) 'The Victims of White Collar Crime' in Lindgren Sven-Ake (ed) White-Collar crime Research. Old Views and Future Potentials: Lectures and Papers from a Scandinavian Seminar National Council for Crime Prevention, Sweden Bra-Report 2001:1.

D’Cruze, S., Walklate, S. and Pegg, S. (2006) Murder, Cullumpton: Willan.

Doyle, A. (2003) Arresting Images: Crime and Policing in From tof the Television Camera, Toronto: University of Toronto Press.

Drakeford, M. (2006) 'How to Explain a Prison Suicide', in Crime, Media, Culture: An International Journal, 2, 2: 217-223.

Ericson, R. Baranek, P. and Chan, J. (1989) Negotiating Control: A Study of News Sources, Milton Keynes: Open University Press.

Evans, J. (2003) 'Vigilance and Vigilantes: Thinking Psychoanalytically about AntiPaedophile Action', in Theoretical Criminology, 7, 2: 163-189.

Ferrell, J. (2005) 'Crime and Culture', in C. Hale, K. Hayward, A. Wahadin and E. Wincup (eds.) Criminology, Oxford: Oxford University Press.

Foster J., Newburn, T. and Souhami, A. (2005) Assessing the Impact of the Stephen Lawrence Inquiry, Home Office Research Study 294, London: Home Office. 
Fracassini, C. (2002) Missing, Scotland on Sunday, August 18 ${ }^{\text {th }}, 2002$.

Galtung, J. and Ruge, M. (1965) 'Structuring and Selecting News', in S. Cohen and J. Young (eds.) (1981), The Manufacture of News: Deviance, Social Problems and the Mass Media, revised edition, London: Constable.

Garland, D. (2000) 'The Culture of High Crime Societies: Some Preconditions of Recent 'Law and Order' Politics', in British Journal of Criminology, 40: 347-375.

Gerrard, N. (2004) Soham: A Story of Our Times, London: Short Books.

Gilroy, P. (1987) There Ain't no Black in the Union Jack, London: Hutchinson.

Goldson, B. (1997) 'Children in Trouble: State Responses to Juvenile Crime', in P. Scraton (ed) 'Childhood' in 'Crisis'? London, UCL Press.

Greer, C. (2003) Sex Crime and the Media: Sex Offending and the Press in a Divided Society, Cullumpton: Willan.

Greer, C. (2004) 'Crime, Media and Community: Grief and Virtual Engagement in Late Modernity', in J. Ferrell, K. Hayward, W. Morrison and M. Presdee (eds.) Cultural Criminology Unleashed, London: Cavendish.

Greer, C. (2005) 'Crime and Media: Understanding the Connections' in C. Hale, K. Hayward, A. Wahadin and E. Wincup (eds.) Criminology, Oxford: Oxford University Press.

Greer, C. and Jewkes, Y. (2005) 'Extremes of Otherness: Media Images of Social Exclusion', in Social Justice, 32, 1: 20-31.

Greer, C., Ferrell, J. and Jewkes, Y. (2007) 'It's the Image that Matters: Style, Substance and Critical Scholarship', in Crime, Media, Culture: An International Journal, 3, 1: 5-10. 
Grubin, D. (1998) Sex Offending Against Children: Understanding the Risk, Police Research Series, Paper 99, Policing and Reducing Crime Unit. London: Home Office.

Hall, S. (1973) 'The Determination of News Photographs', in S. Cohen and J. Young (eds.) (1981), The Manufacture of News: Deviance, Social Problems and the Mass Media, revised edition, London: Constable.

Hall, S. Critcher, C. Jefferson, T. Clarke, J. and Roberts, B. (1978) Policing the Crisis: Mugging, the State and Law and Order, London: Macmillan.

Haydon, D. and Scraton, P. (2000) “'Condemn a Little More, Understand a Little Less": The Political Context and Rights Implications of the Domestic and European Rulings in the Venables-Thompson Case' in Journal of Law and Society, 27, 3: 416-448.

Hayward, K. and Yar, M. (2006) 'The 'Chav' Phenomenon: Consumption, Media and the Construction of a New Underclass' in Crime, Media, Culture: An International Journal, 2, 1: 9-28.

Heaven, O. and Hudson, B. (2005) 'Race, 'Ethnicity' and Crime', in C. Hale, K. Hayward, A. Wahadin and E. Wincup (eds.) Criminology, Oxford: Oxford University Press.

Hillyard, P., Pantazis, C., Tombs, S. Gordon, D. (eds.) (2004) Beyond Criminology: Taking Harm Seriously, London: Pluto Press.

ICAR (2007) Reporting Asylum: The UK Press and the Effectiveness of PCC Guidelines, City University, London. 
Innes, M. (2003) 'Signal Crimes: Detective Work, Mass Media and Constructing Collective Memory', in P. Mason (ed.) Criminal Visions: Representations of Crime and Justice, Cullompton: Willan.

Innes, M. (2004) 'Signal Crimes and Signal Disorders: Notes on Deviance as Communicative Action', in British Journal of Sociology, 55, 3: 335-355.

James, A. and Jenks, C. (1996) 'Public Perceptions of Childhood Criminality', in British Journal of Sociology, 47: 315-333.

Jewkes, Y. (2004) Media and Crime, London: Sage.

Katz, J. (1987) 'What Makes Crime 'News'?', in Media, Culture and Society, 9: 47-75.

Keith, B. (2006) Report of the Zahid Mubarek Inquiry, HC 1082-1, London: Stationary Office.

Kitzinger, J. (1999) ‘A Sociology of Media Power: Key Issues in Audience Reception Research', in G. Philo (ed.) Message Received, London: Longman.

Lees, S. (1995) 'The Media Reporting of Rape; The 1993 British 'Date Rape' Controversy', in D. Kidd-Hewitt \& R. Osborne (eds.) Crime and the Media: The Post-Modern Spectacle, London: Pluto Press.

Leishman, F. and Mason, P. (2003) Policing and the Media: Facts, Fictions and Factions, Cullompton: Willan.

Levi, M. (1999) 'The Impact of Fraud', in Criminal Justice Matters, 36: 5-8. Macpherson, Sir W. (1999) The Stephen Lawrence Inquiry: Report of an Inquiry by Sir William Macpherson of Cluny, CM4262-1. London: HMSO. 
Maguire, M. (2002) 'Crime Statistics: The 'Data Explosion' and its Implications', in M. Maguire, R. Morgan and R. Reiner (eds.) The Oxford Handbook of Criminology, second edition, Oxford: Oxford University Press.

Marsh, H. L. (1991) 'A Comparative Analysis of Crime Coverage in Newspapers in the United States and Other Countries From 1960-1989: A Review of the Literature', in Journal of Criminal Justice, 19, 1: 67-80.

McLaughlin, E. and Murji, K. (1999) 'After the Stephen Lawrence Report', in Critical Social Policy, 19, 3: 371-385.

McLaughlin, E and Murji K. (2001) 'Ways of seeing: the news media and racist violence' in M. May, E. Brunsden and R. Page, Understanding Social Problems: Issues in Social Policy, Oxford: Blackwell.

Meyers, M. (1997) News Coverage of Violence Against Women: Engendering Blame, Thousand Oaks, London: Sage.

Morrison, B. (1997) As If, London: Granta Books.

Muncie, J. (2004) Youth and Crime, London: Sage.

Naylor, B. (2001) 'Reporting Violence in the British Print Media: Gendered Stories', in Howard Journal, 40, 2: 180-194.

Peelo, M. (2006) 'Framing Homicide Narratives in Newspapers: Mediated Witness and the Construction of Virtual Victimhood', in Crime, Media, Culture: An International Journal, 2, 2: 159-175.

Porteous, M. and Colston, N. (1980) 'How Adolescents are Reported in the British Press', in Journal of Adolescence, 3: 197-207.

Presdee, M. (2000) Cultural Criminology and the Carnival of Crime, London: Routledge. 
Reiner, R. (2002) 'Media Made Criminality: The Representation of Crime in the Mass Media', in M. Maguire, R. Morgan and R. Reiner (eds.) The Oxford Handbook of Criminology, third edition, Oxford: Oxford University Press.

Reiner, R., Livingstone, S. and Allen, J. (2003) 'From Law and Order to Lynch Mobs: Crime News Since the Second World War', in P. Mason (ed.) Criminal Visions: Media Representations of Crime and Justice, Cullompton: Willan.

Reiner, R., Livingstone, S. and Allen, J. (2000a) 'Casino Culture: Media and Crime in a Winner-Loser Society' in K. Stenson and D. Cowell (eds.) Crime, Risk and Justice, Cullumpton: Willan.

Reiner, R., Livingstone, S. and Allen, J. (2000b) 'No More Happy Endings? The Media and Popular Concern About Crime Since the Second World War', in T. Hope and R. Sparks (eds.) Crime, Risk and Insecurity, London: Routledge.

Rojek, C. (2001) Celebrity (FOCI), London: Reaktion Books.

Schlesinger, P. and Tumber, H. (1994) Reporting Crime: The Media Politics of Criminal Justice, Oxford: Clarendon Press.

Scraton, P. (1997) 'Whose 'Childhood'? What 'Crisis'?', in P. Scraton (ed) 'Childhood' in 'Crisis'?, London, UCL Press.

Silverman, J. and Wilson, D. (2002) Innocence Betrayed: Paedophilia, the Media and Society, Cambridge: Polity Press.

Sim, J. (2004) 'The Victimised State and the Mystification of Social Harm', in P. Hillyard, C. Pantazis, S. Tombs and D. Gordon (eds.) Beyond Criminology: Taking Harm Seriously, London: Pluto Press.

Solomos, J. (1988) Black Youth, Racism and the State. Cambridge: Cambridge University Press. 
Solomos J (1999) 'Social research and the Stephen Lawrence Inquiry', in Sociological Review Online, $4,1$.

www.socresonline.org.uk/soresonline/4/lawrence/solomos.html accessed $23^{\text {rd }}$ $\underline{\text { September } 2006}$

Sontag, S. 2004. "What Have We Done?” The Guardian (UK), May 24, section G2, pages 2-5.

Soothill, K. and Walby, S. (1991) Sex Crime in the News, London: Routledge.

Sparks, R. (1992) Television and the Drama of Crime: Moral Tales and the Place of Crime in Public Life, Buckingham: Open University Press.

Strange, C. (2006) 'Hybrid History and the Retrial of the Painful Past', in Crime Media Culture: An International Journal, 2,2: 197-215.

Stanko, E. and Lee, R. (2003) 'Introduction: Methodological Reflections', in R. Lee and E. Stanko (eds.) Researching Violence: Essays on Methodology and Measurement, London: Routledge.

Stephenson-Burton, A. E. (1995) 'Through the Looking Glass: Public Images of White Collar Crime' in D. Kidd-Hewitt and R. Osborne (eds.) Crime and the Media; The Post-Modern Spectacle, London: Pluto Press.

Tombs, S. (2005) 'Corporate Crime’, in C. Hale, K. Hayward, A. Wahadin and E. Wincup (eds.) Criminology, Oxford: Oxford University Press.

Tombs, S. and Whyte, D. (2001) 'Reporting Corporate Crime out of Existence', in Criminal Justice Matters, 43: 22-24.

Tombs, S and Whyte, D (eds.) (2003) Unmasking the Crimes of the Powerful: Scrutinising States and Corporations, New York: Peter Lang.

Tombs, S and Whyte, D. (2007) Safety Crimes, Cullompton: Willan. 
Valier, C. (2004) Crime and Punishment in Contemporary Culture, London: Routledge.

Webster, F, (2005) 'Making Sense of the Information Age: Sociology and Cultural Studies', Information, Communications and Society, 8, 4: 439-458. 


\section{Glossary of Terms}

Ethnography - a qualitative research methodology concerned with studying subjects within their own natural environment, frequently involving detailed observation and in depth interviews, geared toward developing an appreciation and understanding of the social world as seen through the eyes of the researched population.

Hierarchy of Victimisation - describes a pecking order of sorts, representing the differential status of particular types and categories of crime victim in media and official discourses, including ideal victims (for example, some child murder victims) at the top of the hierarchy, and non-deserving victims (for example, youths injured in a drunken fight) near the bottom.

Ideal victims - those persons or category of individuals who - when hit by crime - most readily are given the complete and legitimate status of being a victim, including those who are perceived as vulnerable, defenceless, innocent and worthy of sympathy and compassion.

News Values - those criteria that influence, often implicitly, the selection, production and prioritisation of events as news. Key news values include drama and action, immediacy, violence, celebrities, and sex. 
Signal Crimes - a term coined by Martin Innes which refers to those particularly serious or high profile crimes which impact not only on the immediate participants (victims, offenders, witnesses), but also on wider society, resulting in some reconfiguration of behaviours or beliefs (Innes, 2003).

Visualisation of Crime News - the increasing prevalence and importance of visual representations of crime news, crime victims and criminal victimisation in the information age, generally to enhance the immediate accessibility, human interest and overall communicative impact of the news product on media audiences. 